\title{
Possibility, IMAgINATION AND CONCEPTION
}

\section{[POSSIBILIDADE, IMAGINAÇÃO E CONCEPÇÃO]}

Jean-Yves Béziau

Professor na Universidade Federal do Rio de Janeiro (UFRJ)

Natal, v. 23, n. 40

Jan.-Abr. 2016, p. 59-95

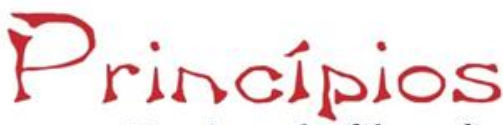

Revista de filosofia 
60

Resumo: Investigamos neste artigo as relações entre possibilidade, imaginação e concepção. Desenvolvemos uma teoria segundo a qual essas três noções são compatíveis, porém independentes, o que significa, em especial, que nenhuma delas é redutível uma a outra e que há coisas que são: (1) imagináveis, mas nem possíveis nem concebíveis; (2) concebíveis, mas nem possíveis nem imagináveis; (3) possíveis, mas nem imagináveis nem concebíveis. Primeiramente explicamos nossa métodologia - estruturalismo, equilíbrio entre norma e descrição, exemplos prototípicos - e então prosseguimos.

Palavras-chave: Quiliágono; Quantum; Contradição; Números imaginários.

\begin{abstract}
In this paper we investigate the relations between possibility, imagination and conception. We develop a theory according to which these three notions are compatible but independent. This means in particular that none of these notions reduces to another one and that there are things which are: (1) imaginable but neither possible nor conceivable; (2) conceivable but neither possible nor imaginable; (3) possible but neither imaginable nor conceivable. We first explain our methodology: structuralism, equilibrium between norm and description, prototypical examples. And then we proceed.
\end{abstract}

Keywords: Chiligon; Quanton; Contradiction; Imaginary numbers. 


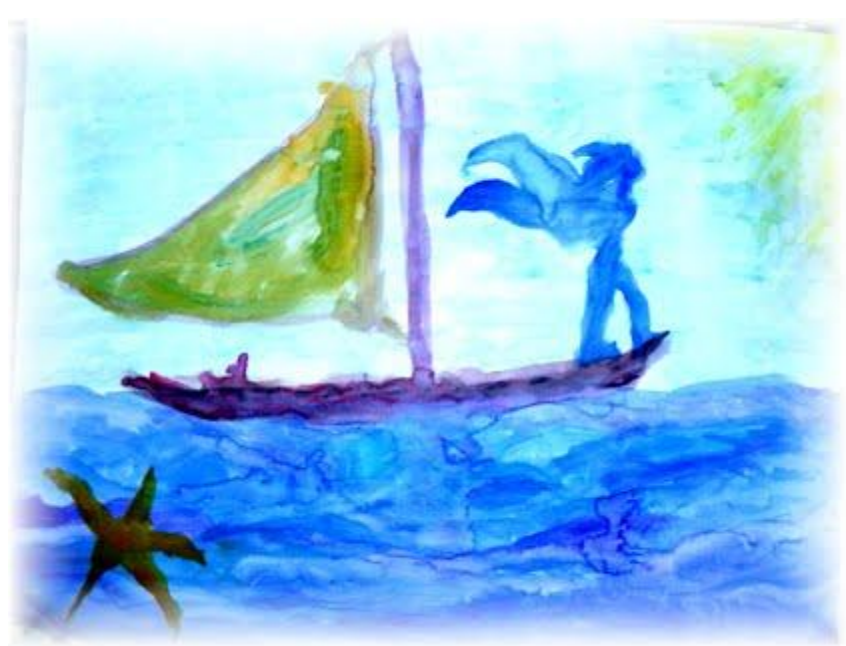

Sur la mer de possibles flotte mon imagination qui,je le conçois, ne peut me servir de boussole.

(Baron de Chambourcy)

\section{Position and methodology}

The aim of this paper is to study the relation between three notions: possibility, imagination and conception. ${ }^{1}$ We develop a theory according to which these three notions are compatible but independent. A picture is worth a thousand words and this can be described using a simple Venn diagram: ${ }^{2}$

\footnotetext{
${ }^{1}$ We use "conception" rather than "conceivability", because the latter can be understood as "what it is possible to conceive", involving the notion of possibility.

${ }^{2}$ In this paper we will use diagrams and images. This makes sense because our paper is about imagination. This is also part of a project we are developing: the promotion of the use of images in philosophy, including the creation of a new journal, The World Journal of Pictorial Philosophy (http://www.wjpp.org). Our present word is dominated by images (advertisements in the street, TV and more and more screens), however philosophers rarely make use of images even at conferences (some philosophers are still
} 


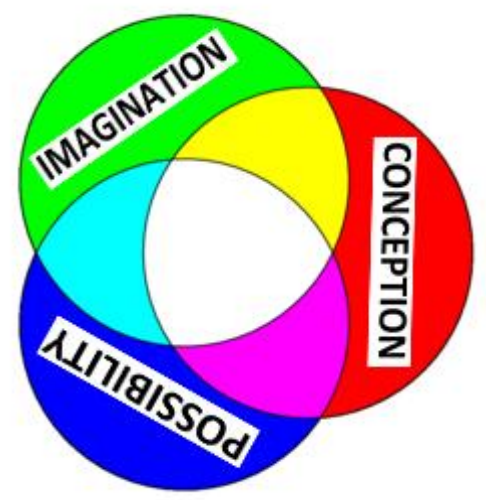

We don't believe that these notions have an inner nature. Our methodology has three main aspects: relational / structural, equilibrium between norm and description and prototypical examples.

Our first methodological option is a relational / structural perspective. $^{3}$ The idea is that a notion can be understood relating it to other notions. In this perspective it is important to make a good choice, to choose the right package. The PIC trinity possibilityimagination-conception is somewhat in the air. ${ }^{4}$ Possibility can also

reading papers). This can maybe traced back to Plato's rejection of appearances.

${ }^{3}$ We could simply say: a structuralist approach, but this is a kind of overloaded word. Nice if our line of investigation is associated with Saussure, Bourbaki, Lévi-Strauss; however this can be too vague or ambiguous. "Relational" is an epithet connected with one of the four meanings of "logos" (science, language, reasoning, relation). Considering this semantic network, we can link "relational approach" to "rational approach" and "logical approach". The structural approach to conceptual analysis has been developed in particular by Blanché, see his seminal 1966 book: Structures intellectuelles. For a recent specimen see Magnani 2016 paper: "Violence hexagon".

${ }^{4}$ About how we started this investigation, see the section of acknowledgments at the end of this paper. A book with the title Conceivability and Possibility was edited by T. S. Gendler and J.Hawthorne in 2002. An item entitled Conceivability, Imagination and Possibility, by Anand Vaidya is on-line since a couple of 
be understood in relation with necessity, virtuality, probability, etc. These are other clusters, complementary rather than concurrent, which can be studied separately in parallel. It is not necessarily a good choice to start with too many notions. There are also other structures, for example the square of opposition and its variations. ${ }^{5}$

Our second methodological option is to find a good equilibrium between a normative and a descriptive approach. For example we don't want to say that imagination is all that has been labelled under this word. Such a descriptive approach would be much confused, and it is probably impossible to find a good characterization of imagination encompassing all what has been called "imagination". On the other hand we don't want to be too normative claiming that imagination is something that has nothing to do with what has been called "imagination", in this case it would be better to use another word. ${ }^{6}$

According to the above Venn diagram there are 7 situations, we will focus on the three exclusive primary cases: pure imagination (green), pure conception (red), pure possibility (blue), but also we will discuss the three secondary cases: things which are imaginable and conceivable but not possible (yellow), things which are possible and conceivable but not imaginable (magenta), things

years at Philpapers but the author has up to now not written any paper or book with such a title, only an article entitled "The epistemology of modality" (Vaidya, 2007, 2015) to which the above item is linked.

${ }^{5}$ For an approach of possibility using other packages and the square see our recent papers: "Le possible et l'impossible: au-delà de la dichotomie?" (2016), "The contingency of possibility?" (2016).

${ }^{6}$ Before Alice starts to criticize the views of possibility, imagination and conception presented in this paper, whose configuration is summarized in our PIC Venn's diagram, it would be good for her to re-read three times the paragraph to which this footnote is attached: the present version with imagination, the version with conception and the version with possibility. As it is known from the Hunting of the Snark: three leads to truth. And playing with words is playing with fire, so if Alice doesn't want her mind to be set on fire, she has to take seriously what we are talking about, words being a slippery surface. 
which are possible and imaginable but not conceivable (cyan). ${ }^{7}$ Instead of giving many examples we will try to exhibit prototypes.

We think that prototypical example is a good methodology for the development of conceptual analysis. It fosters an approach that can be qualified as comprehensive, giving understanding of a concept through a concrete example able to catch unity beyond multiplicity and variety. ${ }^{8}$ This threefold methodology aims at conceptual clarification - cf. the title of our recent tribute book to Patrick Suppes (2015) and the 1944 paper by Tarski on truth ("we should try to make these concepts as clear as possible" says Alfred to us).

Let us start with a first prototype, characterizing the 7th slice of our Venn diagram, the white one at the middle, corresponding to things which are at the same time possible, conceivable and imaginable. Our prototype here is an omelet.

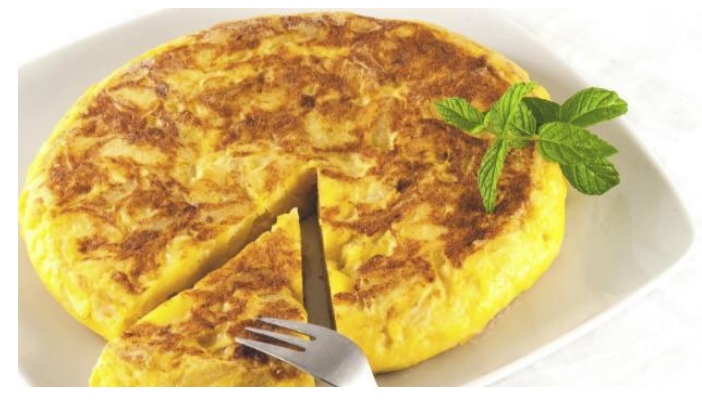

7 The diagram we are using is a classical Venn diagram representing the relations between primary and secondary colors. For an approach of the theory of colors based on the hexagon of opposition, see the 2012 paper by Dany Jaspers "Logic and Colour". The choice of the specific correspondence between PIC and $R B G(P=B ; I=G: R=C)$ is ours, it is related to the connection we have established between RBG and the three notions of opposition of the square, see our papers "The new rising of the square of opposition" (2012) and "The power of the hexagon" (2012).

${ }^{8}$ For more details about this approach, see our forthcoming paper "Prototypical conceptual analysis". This methodology is connected with symbolization; see our 2014 paper "La puissance du symbole". 
This is something you can easily imagine (see the above picture), conceive (have a look at a recipe) and possible (start cooking!).

After this delicious mise en bouche, let us proceed to the main course...

\section{Imagination}

We understand imagination here in direct relation with images, in particular material images: a painting, a drawing, a photograph, a reflection in a mirror or in the water, a movie. A material image can be a representation of a concrete reality or of an abstract reality. Compare the two following images:
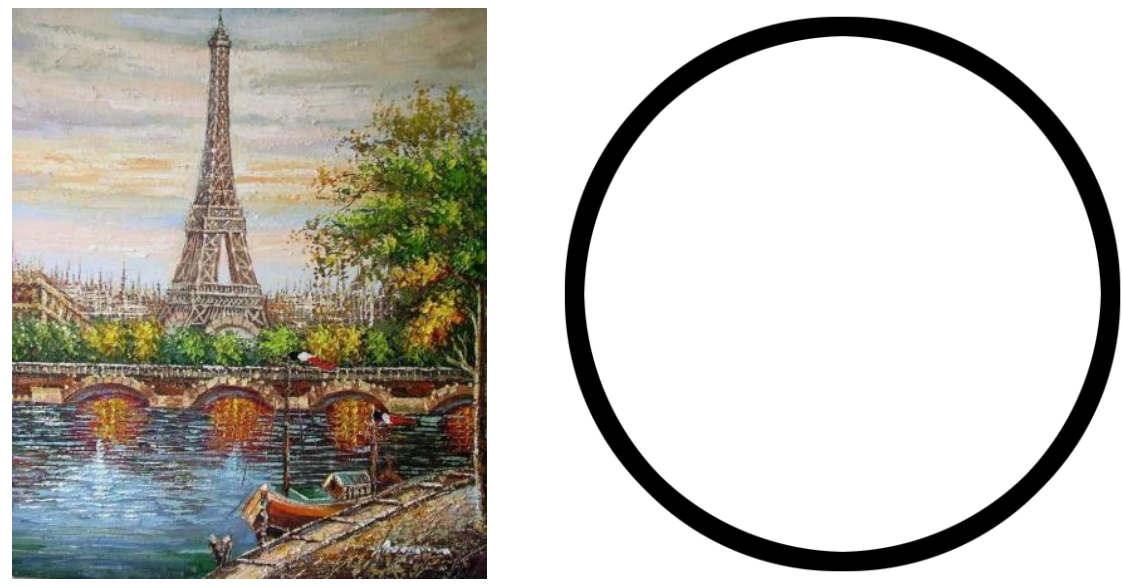

The image of a circle can be considered as a materialization of an abstract idea: a line that is curved so that its ends meet and every point on the line is at the same distance from the center. On the other hand this idea can be seen as an idealization of concrete realities: 

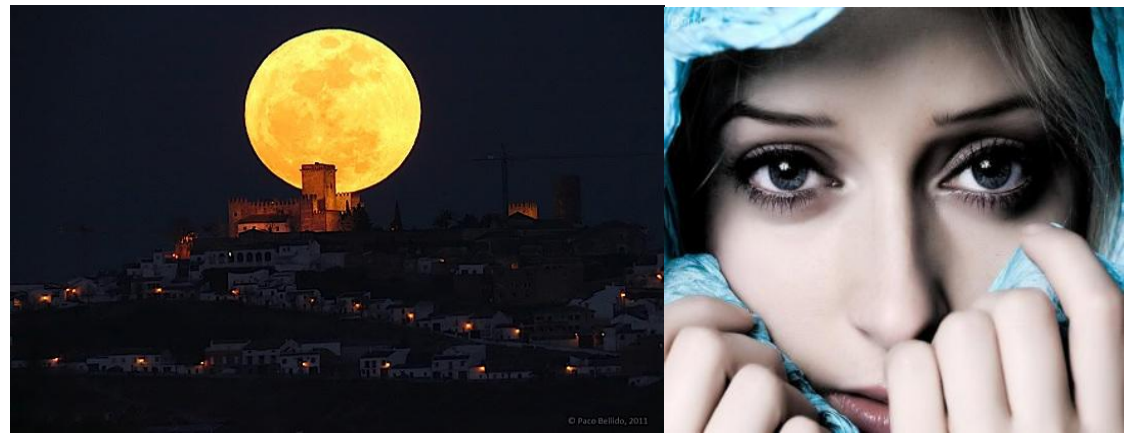

However this is not the same as an image describing a specific object like the above painting of the Eiffel tower.

Images can be used to create a concrete reality, for example images of the Eiffel tower were produced before its construction:

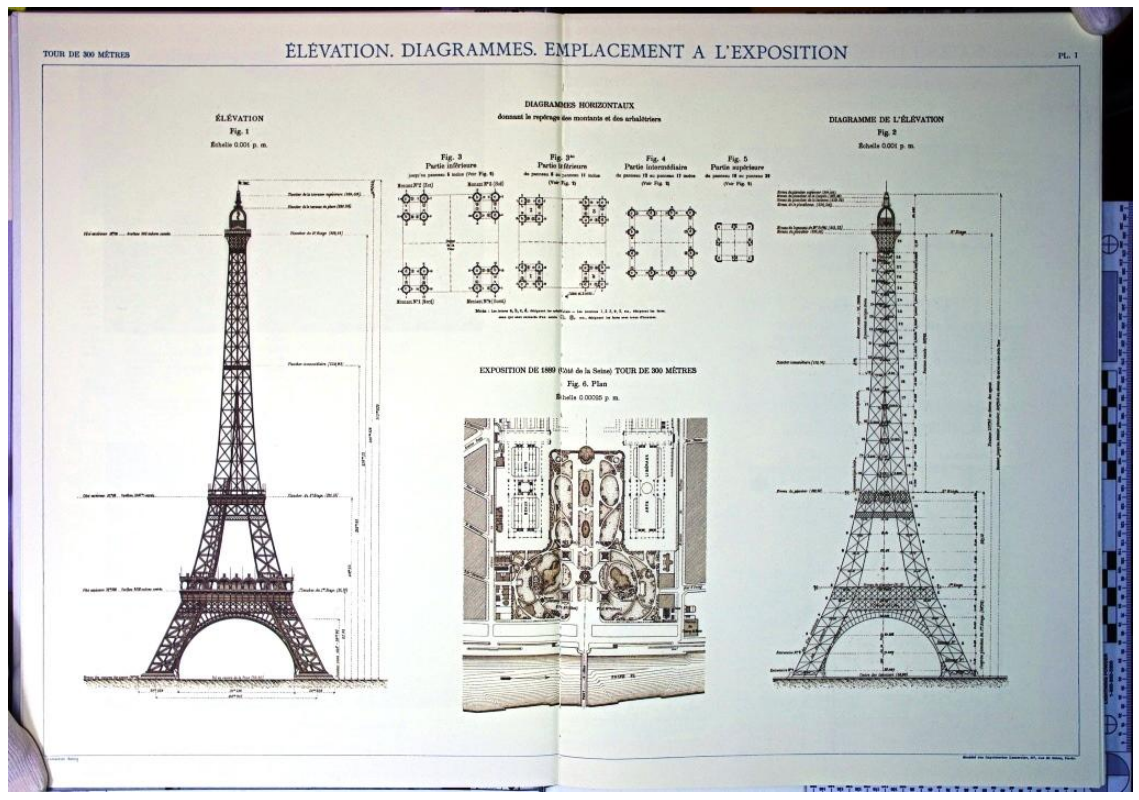

Princípios:Revista de Filosofia, Natal, v. 23, n. 40, jan.-abr. 2016.ISSN1983-2109 
But many images do not correspond to real objects, entities or events, like the image of a centaur, a smurf or some images produced by special effects:

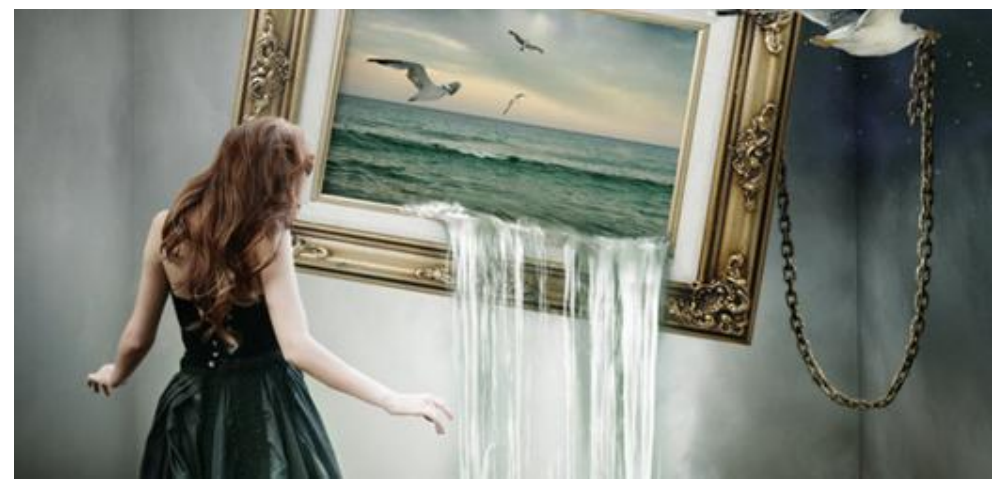

It is easy to create images of impossible things. This was done quite a lot at the beginning of the history of the cinema, in particular by Georges Méliès (1861-1938). One of his most famous movies is A trip to the moon (Le voyage dans la lune, 1902).

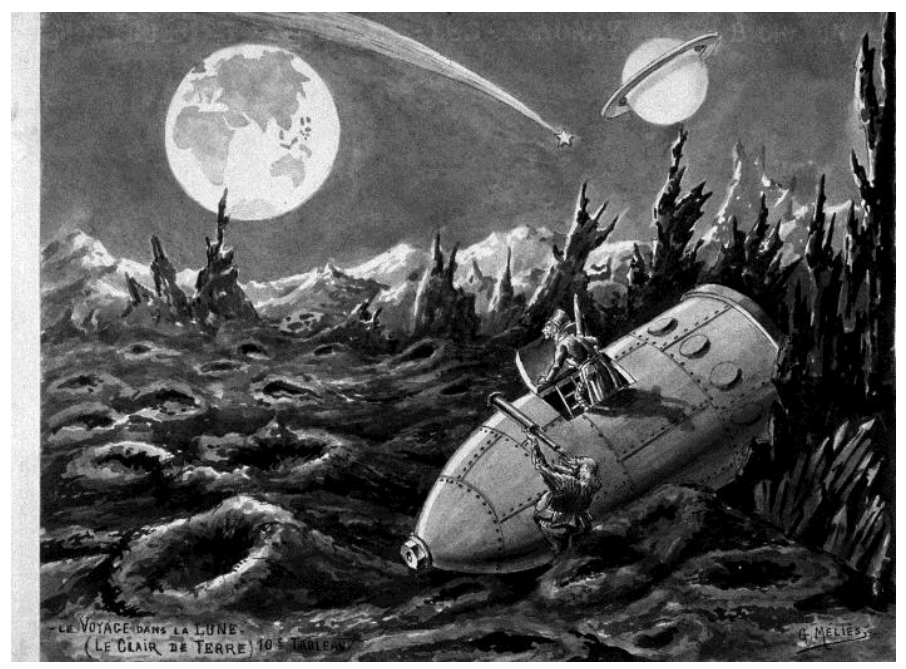

Princípios:Revista de Filosofia, Natal, v. 23, n. 40, jan.-abr. 2016.ISSN1983-2109 
At this time it was not possible for human beings to go to the moon. After 1969 we can say it is not only imaginable but also possible (although some people are arguing that the moon images, such as the one below, are due to Stanley Kubrick, famous for producing and directing 2001: A space odyssey in 1968).



Going to the moon is conceivable in the sense that we have a theory explaining how we can do that. Travelling to Mars is also imaginable and conceivable. There may be many disparities between imagination and conception. A movie about a trip to Mars can be produced with lots of special effects which do not correspond to the theory explaining "step by step" how to go there, similar to the plan of the Eiffel tower, which led to the realization of the worldwide famous building. Such a monument is part of the same genus as the omelet, but not a trip to Mars.

On the basis of a screenplay or a storyboard we can realize a movie, but we should not confuse such a "realization" with reality. When saying that a travel to Mars is conceivable "step by step" we 
are not talking about a screenplay but something closer to Eiffel tower's plan. But it is not because we have such kind of plan that this is "really possible." At the present time a travel to Mars is typically in the yellow zone of our diagram: something imaginable, conceivable but not possible. Note however that we don't reduce possibility to realizably. For example it is certainly possible to paint the Eiffel Tower in blue even it has never been done.

The reason why a trip to Mars can turn to be impossible despite its conceivability is because our theory can be wrong. Consider Escher's waterfall. By difference to the picture presented earlier representing a waterfall product of a photomontage, we have with Escher's drawing something more similar to the Eiffel Tower's plan. Is Escher's waterfall based on a drawing treachery? Anyway this drawing is based on conceptualization; a conceptualization which can nearly lead to the realization of this waterfall, as shown by the Lego construction of Andrew Lipson (2003). Note on the other hand that the strange conceptual image of a Möbius strip is really possible.

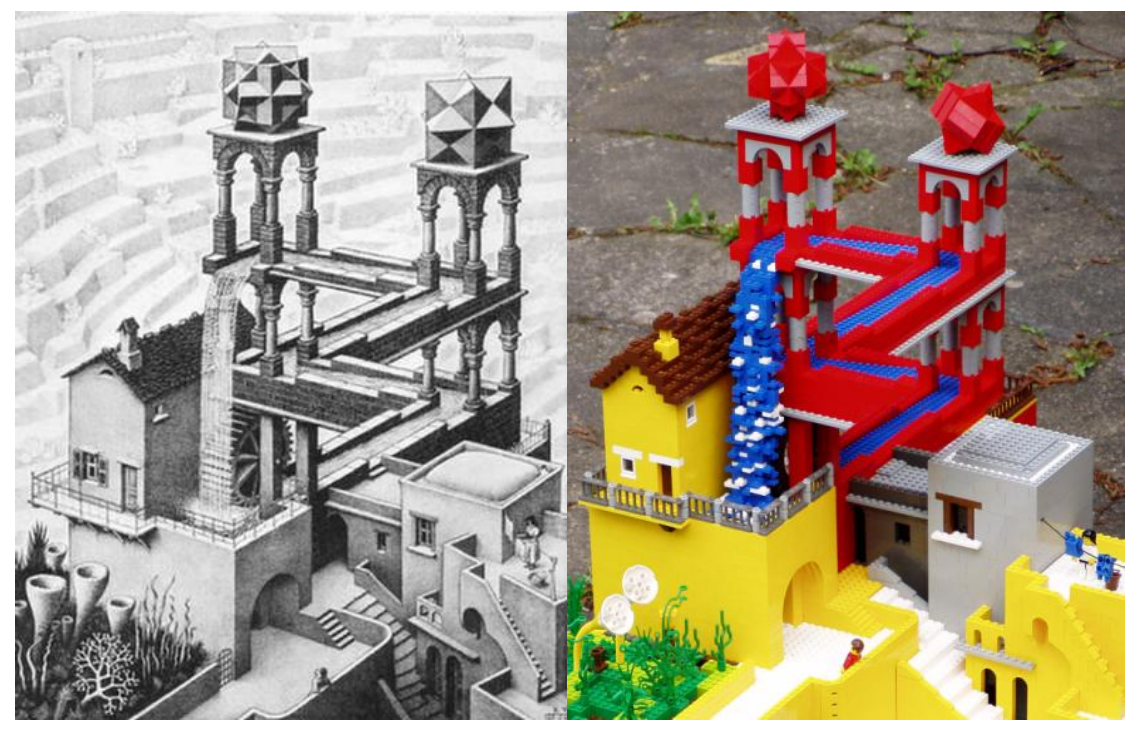


A travel out of the solar system is something we can imagine but not conceive, we have no theory at this stage explaining how to do it. And this is presently not possible. But something can be possible even if we cannot conceive it, we will be back to this on Section 3. And also it not because something is conceivable, that it is possible, we will talk about that in Section 2.

Anyway without going out of the solar system and/or travelling in time, we can give a simple example of something which is imaginable but neither conceivable nor possible: a flying pig, like Adynaton represented in the picture below, who kindly agreed to be our prototype of "green" entity.

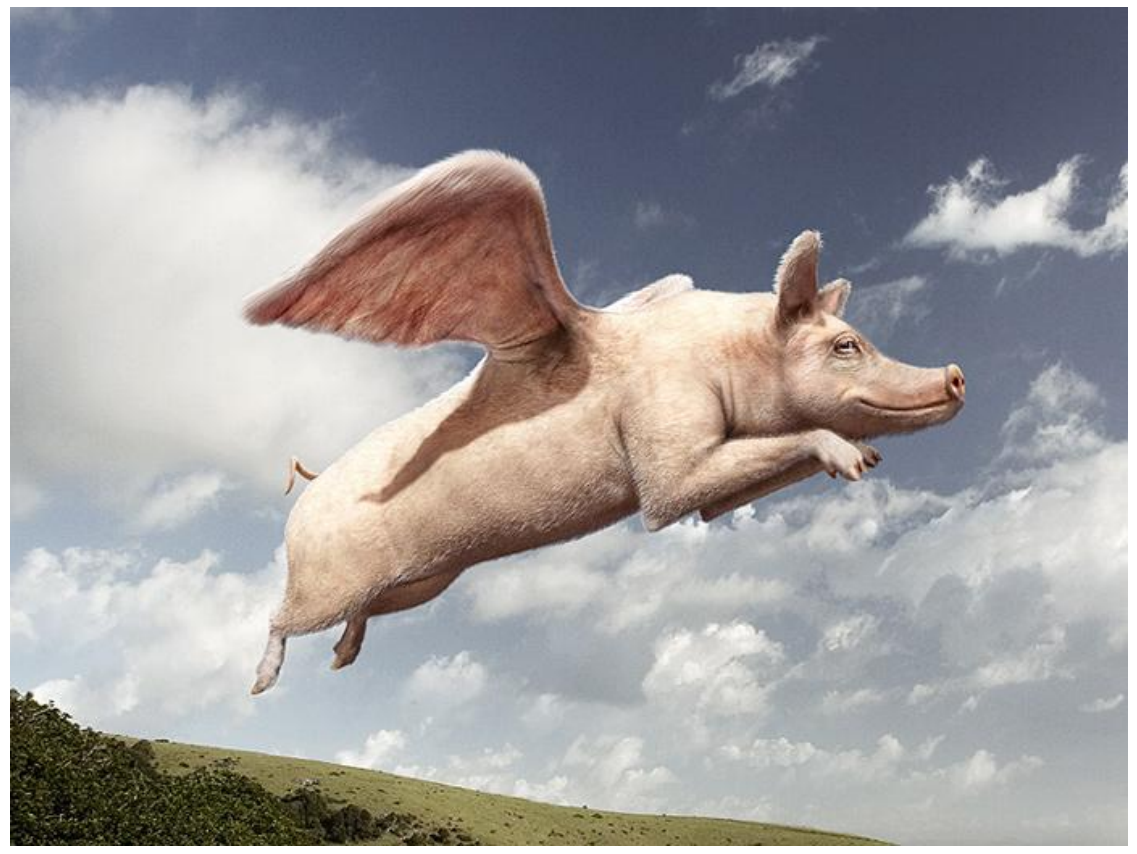

But with the advances of science, this flying pig may be one day conceivable. This would be a giant leap for mankind. 


\section{Conception}

It easy to find things which are conceivable but not imaginable - a typical example is the famous chiliagon of Descartes. A chiliagon is a polygon with 1.000 sides.
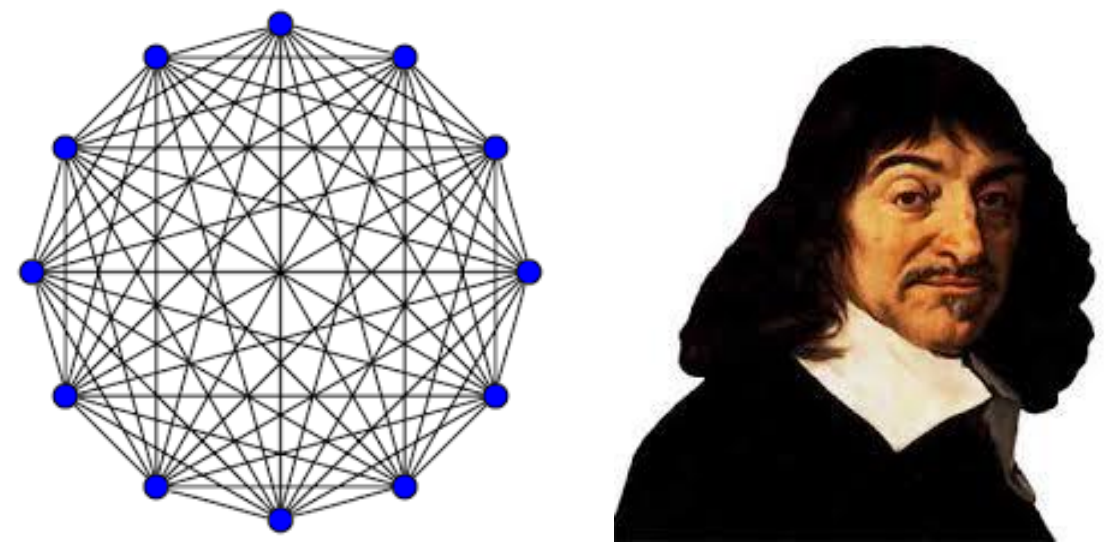

The above left picture is NOT a chiliagon, it is a dodecagon. It not easy for us to concretely draw a chiliagon on a piece of paper, however this is not technically impossible. But it is clear that we cannot have a mental image of it just closing our eyes. Note also that one can argue that the above picture is not Descartes, but just an approximation of his face.

Our brain cannot imagine what a chiliagon is but a computer can do it, in the sense that it can construct quite easily and quickly a concrete image of a chiliagon in a screen. ${ }^{9}$ Does this mean that computers are imaginative? Maybe not so much. Can a computer imagine what aleph zero is, or, more simply, what the empty set is? It can at least produce the two beautiful symbols for them:

\footnotetext{
${ }^{9}$ About the brain and mental images see our joint paper with Suppes (2004) and correlated works published by Suppes Brain Lab.
} 



It is also not clear at all that human beings can imagine aleph zero and the empty set. These can be considered as purely conceptual objects like many mathematical objects, including imaginary numbers. Do we have an image of an imaginary number?
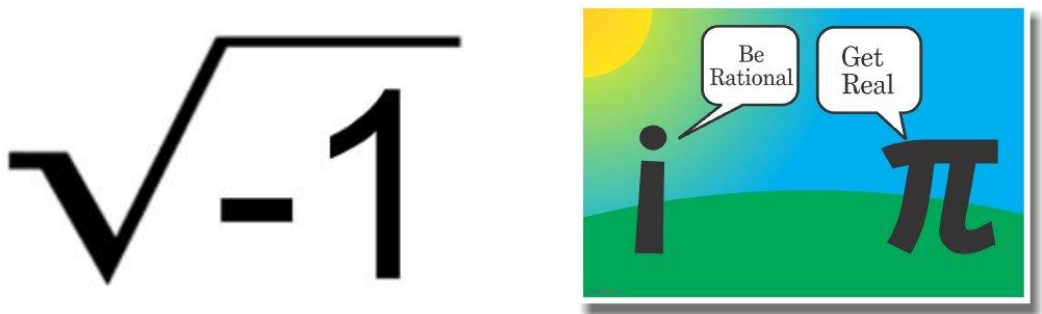

Real numbers, although very abstract, can be called real because they are in connections with reality; they are used to describe, understand, modify reality. But are imaginary numbers in connection with imagination? One of the possible origins of this terminology is the association between creativity and imagination. Such an association can be considered also as backing expressions such as Imaginary geometry and Imaginary logic, both being in fact against imagination as an images driven faculty. Imaginary geometry, also called Non-Euclidean geometry, is geometry rejecting the parallel postulate. It was developed in particular by Nikolai Lobachevsky (1792-1852). Nicolai Vasiliev (1880-1940), also from Kazan, inspired by the former developed a logic rejecting the 
principle of non-contradiction he called by analogy Non-Aristotelian logic or Imaginary logic. ${ }^{10}$ In both cases these are theories more abstract than the basic ones and not based or motived by some images.

Reducing creativity to imagination is not a very sophisticated idea. Creating images (real or mental) can be seen as the easiest form of creation. This is something that every human can do, not something we need to dream of. Mathematics and music are in fact good examples of strongly creative activities not necessarily based on or connected with images.

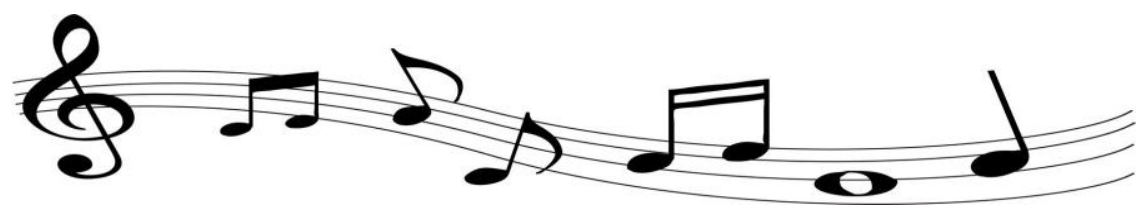

We may have images of strange mathematical objects like Möbius strip:

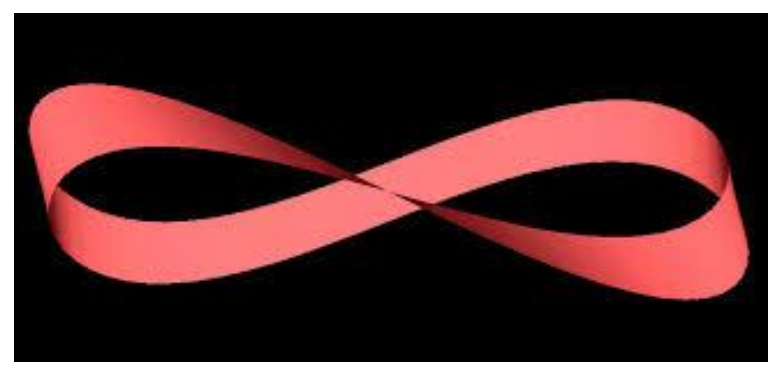

\footnotetext{
${ }^{10}$ For this reason Vasiliev is generally considered as the forerunner of paraconsistent logic which was later on developed by Stanislaw Jaśkowski (19061965) and systematically by Newton da Costa (1929-). About the work of Vasiliev, see the IEP entry by Bazhanov (2016), our paper "Is modern logic non-Aristotelian?" and other papers in the book edited by D. Zaitsev following the congress organized in honor of Vasiliev in Moscow in 2012, as well as the recent paper by Maximov (2016).
} 
However mathematical objects like transfinite numbers are typically things which are conceivable but difficult to imagine, even if the proof that the real numbers are not denumerable can be "seen" by a diagonal proof: ${ }^{11}$

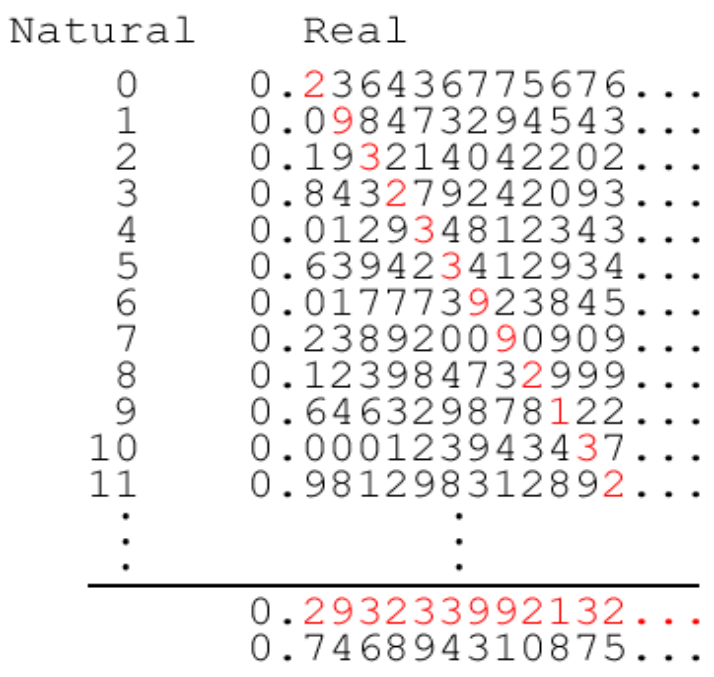

Now can we say that $\aleph_{0}$ and his transfinite sisters are possible? Possibility can here be connected with consistency / noncontradiction. As we know, there are no absolute proof of the existence of transfinite numbers or even natural numbers, in the sense that there are no absolute proof of the consistency of arithmetic and set theory. On the other hand some mathematical objects are typically not possible in the sense that they are contradictory, for example a curved straight line. And these kinds of objects are also not product of imagination. For example the following is not an image of a curved straight line:

\footnotetext{
${ }^{11}$ About visual proofs see the two volume book by Nelsen (1997-2000), the book by Shin and Moktefi (2013) and the paper by L. Choudhury and M. H. Chakraborty (2016).
} 


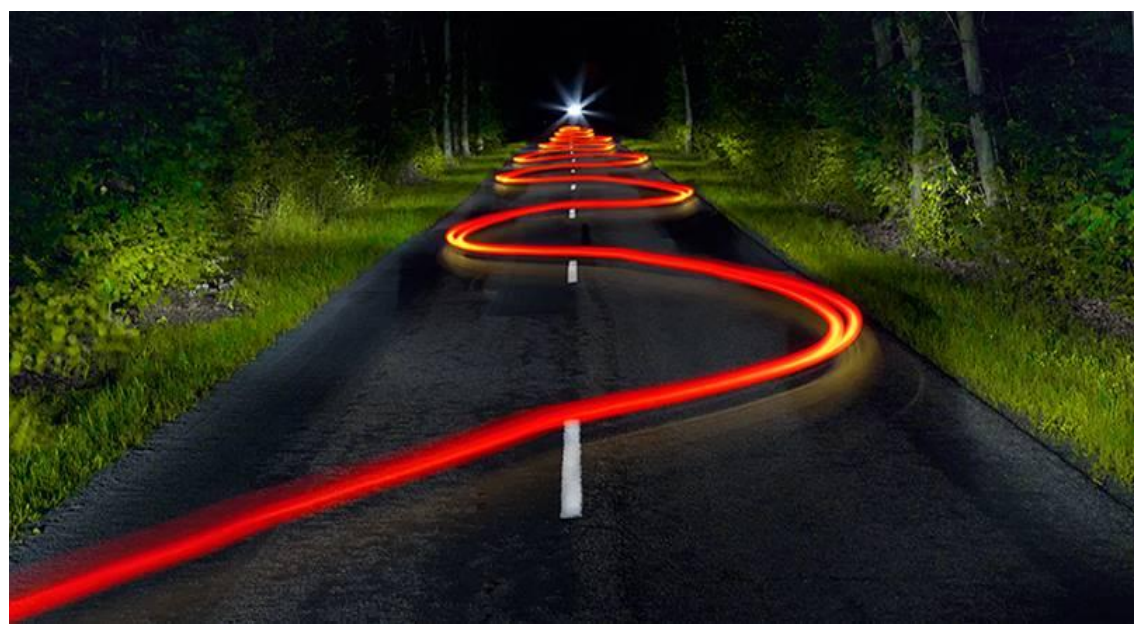

A curved straight line can be considered as a prototypical contradictory object. The notion of contradiction itself can be considered as a prototype of something that is conceivable but neither possible nor imaginable. The notion of contradiction is conceivable; in particular we can define it, either in the framework of the square of opposition or propositional modern logic:

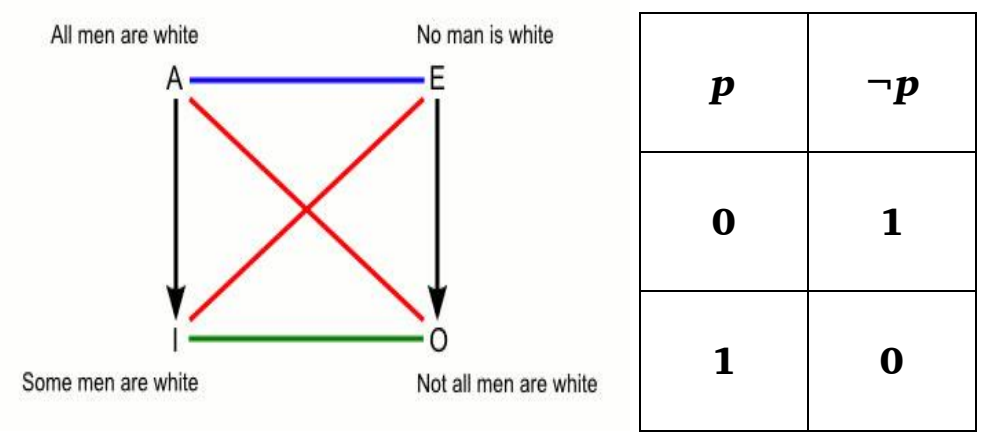

On the right we have the truth-table for classical negation saying that $p$ and $\neg p$ form a contradiction, because they can 
neither be true together nor false together (truth being represented by 1 and falsity by 0 ). This is the definition of classical negation, directly related with the notion of contradiction of traditional logic that can be found on the theory of the square of opposition. ${ }^{12}$

On the left the square of opposition defines two contradictory propositions as two propositions that can neither be true nor false together; the contradictory relation is represented in red in the above picture. In blue we have the relation of contrariety: two propositions are contrary if and only if they can be false together but not true together. An example of contrary object is a round square, because the two propositions " $x$ is a square" and " $x$ is a circle" cannot be true together but can be false together, for example $x$ can be neither a square nor a circle, it can be a triangle. The fact that frequently people give as a typical example of contradictory object a round square shows that there is a tendency to confuse the notions of contradiction and contrariety. ${ }^{13}$

Anyway a contrary object, as a round square, is also something like a contradictory object that is neither possible nor imaginable, unless we have a weak logic of imagination according to which if we imagine $A$ and we imagine $B$ therefore we imagine the conjunction of both, in symbols: $\circ A \wedge \circ B \rightarrow \circ(A \wedge B)$; the ball representing here a modal operator of imagination. This is imagination by juxtaposition as represented by the following simple round square and a round square haircut (better tangled):

\footnotetext{
12 About recent advances on the square of opposition see Beziau and Payette (2008 and 2012), Beziau and Jacquette (2012), Beziau and Read (2014), Beziau and Gan-Krzywoszynska (2016), Beziau and Basti (2016), Beziau and Giovagnoli (2016).

13 About a detailed analysis of this question see our 2015 paper "Round squares are no contradictions", and discussing more specifically the confusion between contrariety and contradiction: Becker Arenhrat 2015 paper "Liberating paraconsistency from contradiction" and our 2016 paper "Disentangling contradiction from contrariety via incompatibility". The distinction between the two concepts is attributed to Aristotle, but it may have been anticipated by Plato (see Lachance, 2016).
} 



Someone may argue that the axiom $\circ A \wedge \circ B \rightarrow \circ(A \wedge B)$ is also absurd if the ball symbolizes conception. In which sense are we really conceiving a round square or a curved straight line? We can argue that the notions of contrariety and contradiction are conceivable because we can precisely define them, but do we have a clear idea of what they are? Is it not just a juxtaposition of concepts similar to a juxtaposition of images? Can we say that a juxtaposition of images does not always form an image but that a juxtaposition of concepts always forms a concept? The fact that there is no object corresponding to a concept is not necessarily against a positive reply to that question. We can say that a mathematical theory, like naïve set theory based on the axiom of abstraction (any property determines a set), has a conceptual flavour even if it is inconsistent.

We can leave this question open. If we consider that the abstract notion of contradiction is something that we can conceive, but not imagine and which is not possible, we are not obliged to consider that a particular case of contradiction is an object of this kind, we may consider that it is not conceivable.

Let us now have a look at the following picture which has been used by physicists to metaphorically represent the wave/particle duality: 


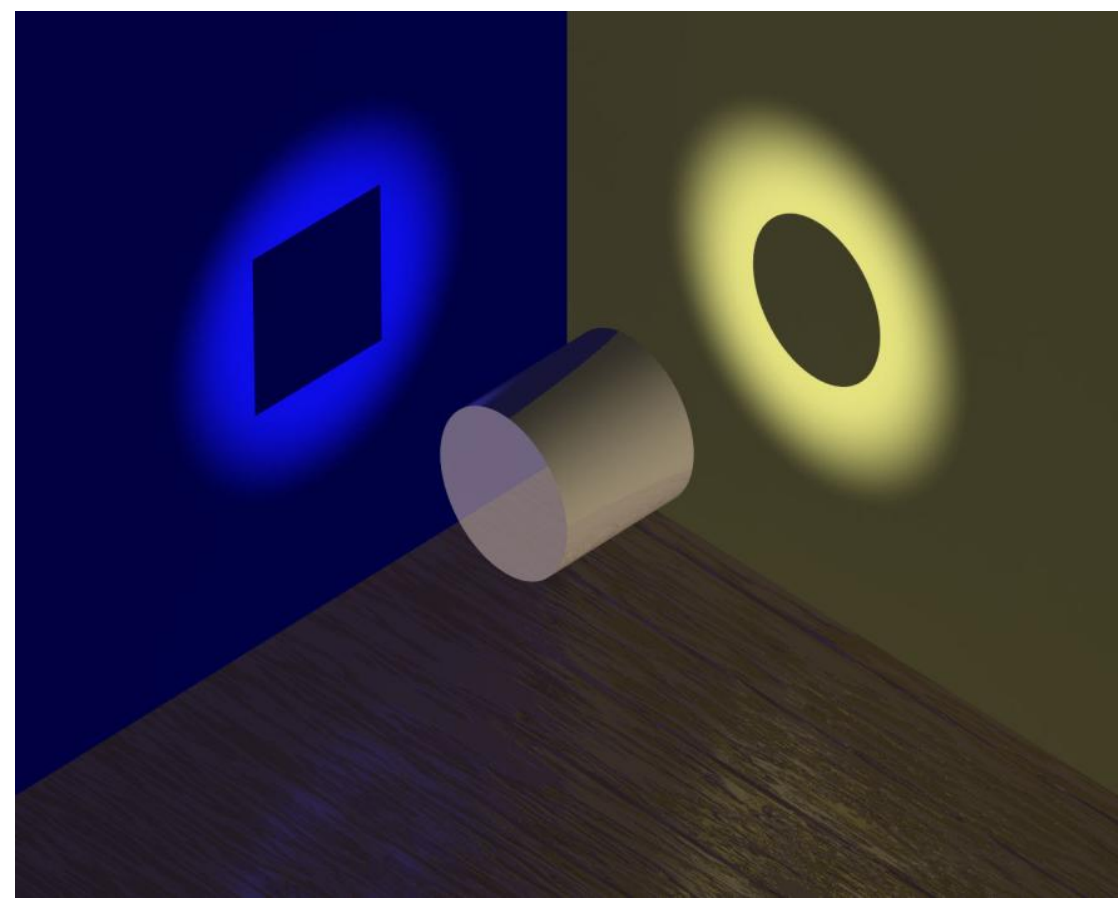

According to this picture something may appear as a square and as a circle. But a cylinder is indeed neither a square nor a circle. Following this metaphor an object can appear as a wave, or a particle, but is neither a wave nor a particle. But then what is it? We have presently no way to imagine it. Mario Bunge (1967) has introduced the word quanton to talk about the objects of quantum physics, this name has been used for example by M. Lévy-Leblond and F. Balibar but it is still quite fashionable to talk about elementary particles, in particular in literary circles. Although physical theories can give us a good account of microscopic reality, in particular in terms of prediction, we have no clear image of it, a microscope in particular does not provide corresponding images.

We can consider quantons as prototype of magentaic objects, those objects which are in the magenta zone of our Venn's 
diagram. We can conceive this kind of objects and they are possible, but we cannot imagine them. Different interesting philosophical approaches to modern physics have been defended by people like Bernard d'Espagnat (1921-2015) or David Bohm (1917-1992), a former collaborator of Einstein, both of whom I have been working with (see my 1987 dissertation).

Albert Einstein himself is famous for the following quotation:

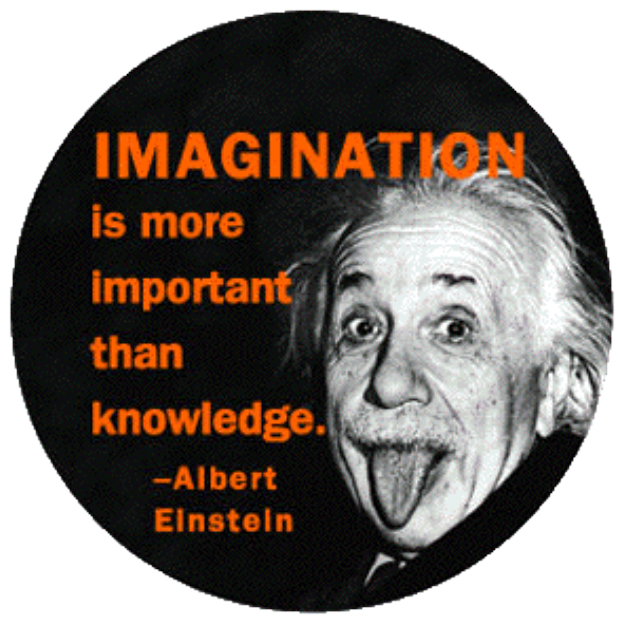

The continuation of the quotation is: "For knowledge is limited to all we know and understand, while imagination embraces the entire world, and all there ever will be to know and understand". According to this vision, imagination is a super faculty of our mind. It is not clear which kind of power it is. Here again it seems that imagination is associated with something like creativity and is not directly based on images. As we have pointed out we can conceive microscopic reality even if we don't have images of it. We can say the same about macroscopic reality. The theory of relativity is based on non-Euclidean geometry, something hard to imagine, which does not properly match with the images given by telescopes. 
Another quotation about imagination attributed to Einstein is: "Logic will get you from A to B. Imagination will get you everywhere". Here also it is not clear what is this magic faculty called imagination. These quotations have been largely promoted and give an ambiguous idea of science, Einstein being considered as one of the most famous scientists. People without much capacity of reasoning may feel like scientists of genius imagining absurdities.

There are many things we can understand that we have no images of. It is therefore misleading to say they are products of our imagination. Someone could claim in a neo-Platonic fashion that reality is beyond imagination; that it can only be reached by the eyes of reason. And logic (reasoning) has got us to some places we were not even able to dream of, for example in front of a HDTV, drinking coca-cola and closely watching tigers without the risk of being eaten.

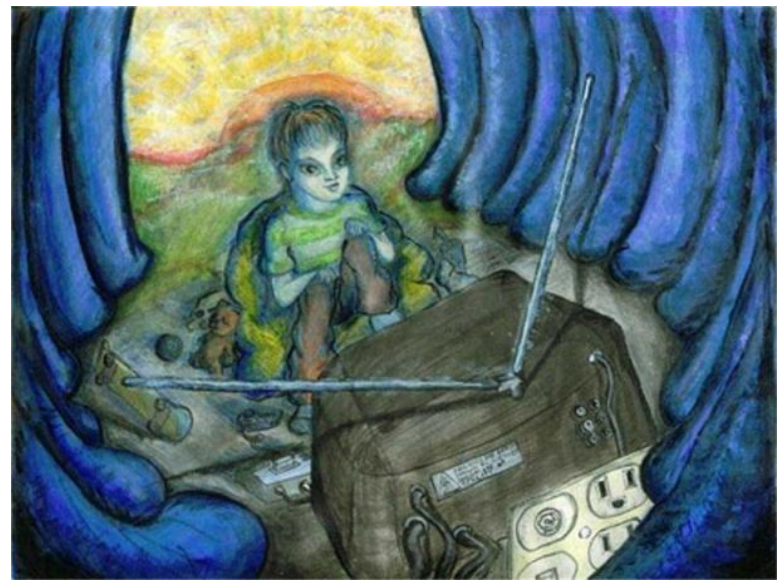

On the other hand images can be used in many different interesting ways, in particular in a negative way as Plato did with the image of the cave, or metaphorically as with the above cylinder picture. 


\section{Possibility}

Everything is possible. This can be understood in two different ways, a vulgar mode and a more sophisticated one. The vulgar one has been used by people like Sarkozy who with a popular futurist variation of this magic sentence was elected president of France in 2007.

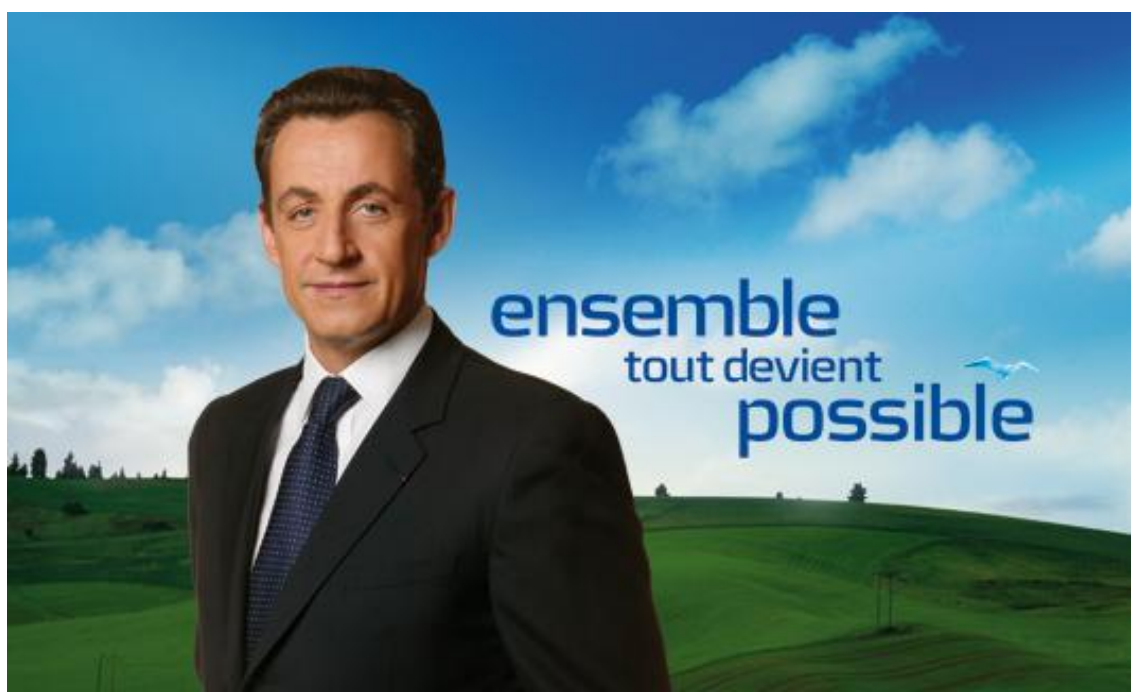

The more sophisticated mode is that possibility is a modality which applies, successfully or not, to everything: actions, events, ideas, theories, beings. It is a kind of universal operator: given $\mathrm{X}$, we can talk about possible X. In modal logic, possibility is represented by the sign " $\diamond$ ", poetically called a diamond. But in this context, possibility generally applies only to propositions. Let us emphasize that possibility in modal logic is only one possible aspects of possibility.

Possibility applies to imagination and conception. Conceivable is what it is possible to conceive and imaginable what it is possible to imagine. By contrast to imagination and conception, possibility 
is not restricted to a faculty. It is also ontological. What is the exact relation between possibility and reality? We can reasonably say that reality is possible; in particular what happens is possible. But possibility is larger than reality. Many things that are possible are not necessarily happening.

In previous sections we have seen examples of things of imagination and conception which are not possible. We will now see examples of things which are possible but which are neither conceivable nor imaginable. First let us start with something easier, the realm of the cyanic things, those who are both possible and imaginable, but not conceivable. A simple example is a tree:



Princípios:Revista de Filosofia, Natal, v. 23, n. 40, jan.-abr. 2016.ISSN1983-2109 
This tree is possible and imaginable. Now can we really conceive it? Do we have a theory explaining exactly what this tree is? A botanist may say yes. But Sartre facing the Nausée may say no. Biology is a science which typically has developed through classification and one of the keys of classification is the tree structure, ${ }^{14}$ easier to imagine than a real tree, but giving us only a partial vision of the essence of the tree:

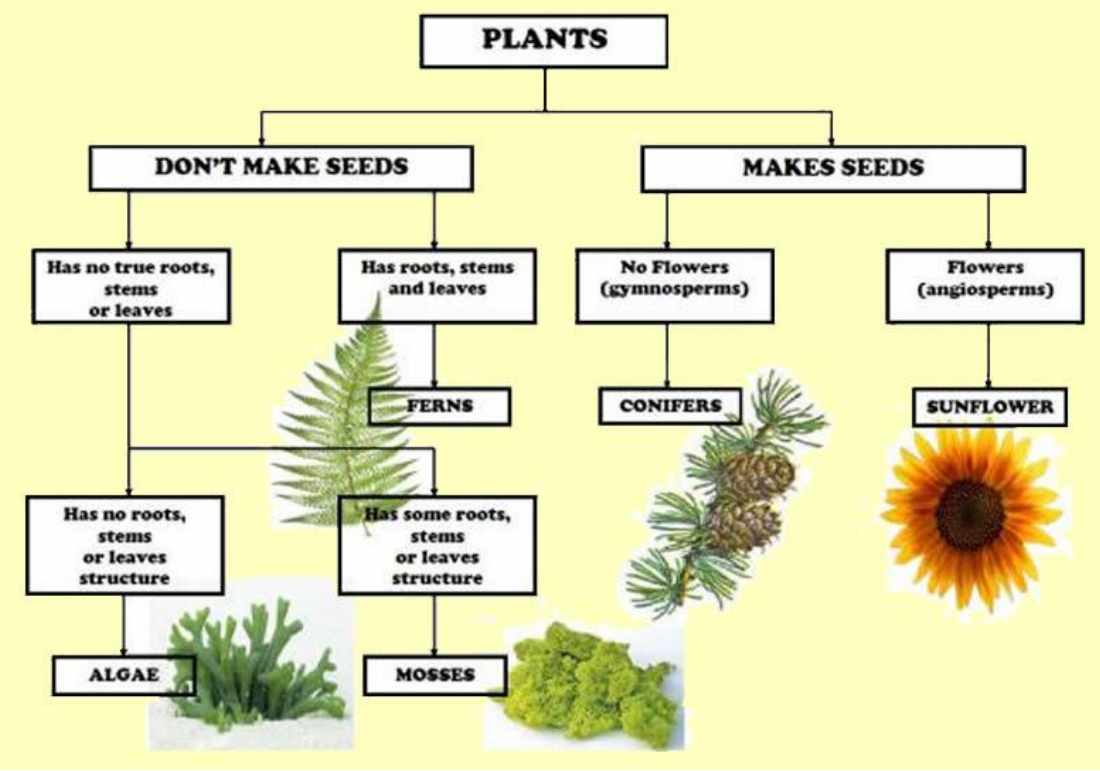

Now let us go further on, when imagination lets us down. We can produce a picture, a painting, a mental image of a tree. But can we do the same about the whole reality in which this tree is merged in?

${ }^{14}$ On the theory of classification, see the recent book of Parrochia and Neuville (2012). 
Let us start with a short story by Fredric Brown written in 1955 called Imagine:

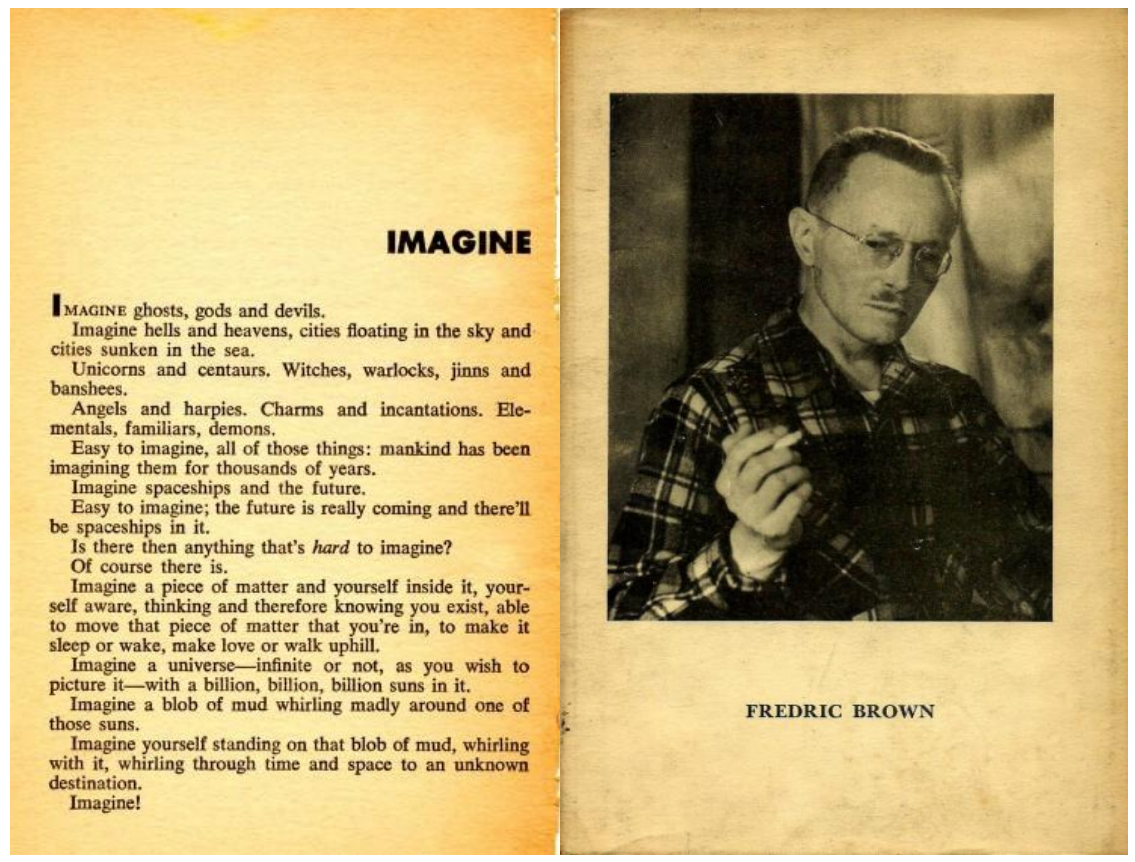

Fredric Brown (1906-1972) was an American writer, authors of several novels, both mysteries (e.g. One for the road), science fiction (e.g. What mad universe), but he is considered as a master of short stories in particular of short short stories, sometimes also called flash fictions. Can we however call the above text a fiction, a story? A story of what? In the end nothing happens! What is interesting about this text is that Brown, a champion of imagination, points out that reality is more incredible or absurd than anything we can imagine. 
Can we imagine the world? Possible worlds have become quite popular recently but what about the real world? Here is a possible image of it:

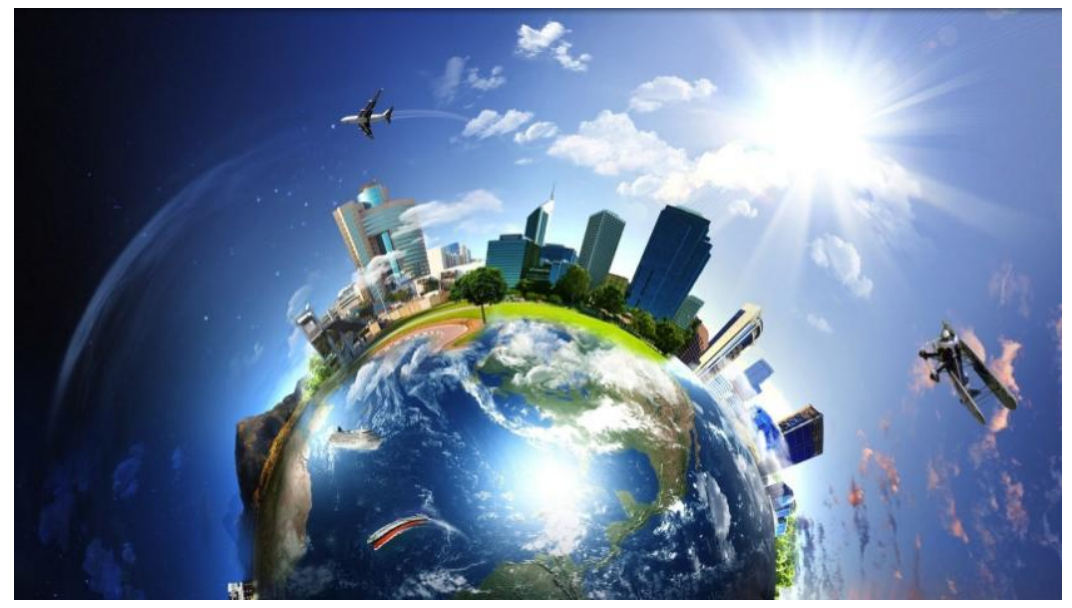

Maybe in the future this image will appear as absurd as the following picture of pseudo-Indian mythology.

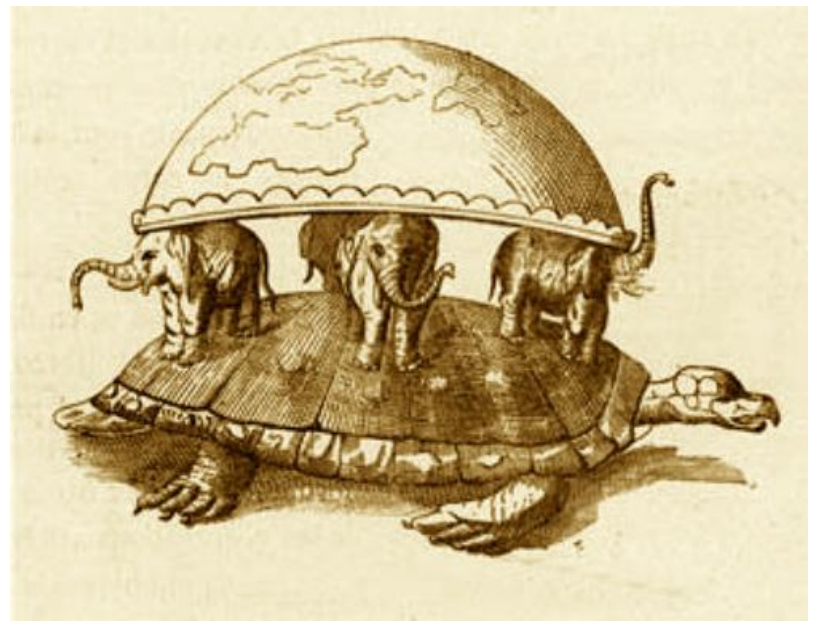

Princípios:Revista de Filosofia, Natal, v. 23, n. 40, jan.-abr. 2016.ISSN1983-2109 
In fact the above modern image is already absurd in the sense that it is centered on the earth, as if reality reduced to that "blob of mud".

A more general image would be an image of the universe:



But such an image reflects only one aspects of reality. It does not give an account of the sense of life. The same can be said about the conception of the universe given by physical theories. That is why we can say that reality is not conceivable. Sense of life is an ambiguous expression; some people prefer to talk in a more pataphysical way.

"Life" can be used to talk about reality or a particular phenomenon part of it, life in a biological sense. Despite the development of biology, we can say that life in a biological sense is still a mystery, whose conceptualization is still pretty immaculate. And what kind of generic image can we have of life encompassing entities as varied as cats, trees, human beings and the surrounding mystery? Here is one given by Lewis Carroll: 
Jean-Yves Béziau



Princípios:Revista de Filosofia, Natal, v. 23, n. 40, jan.-abr. 2016.ISSN1983-2109 
But this is a very metaphorical image of life. If you don't know where you are going, any road will get you there: this is roughly speaking the message of the cat. Anyway all paths lead to death, something which is also neither easy to conceive nor to imagine. Here is a symbolic image of Death:

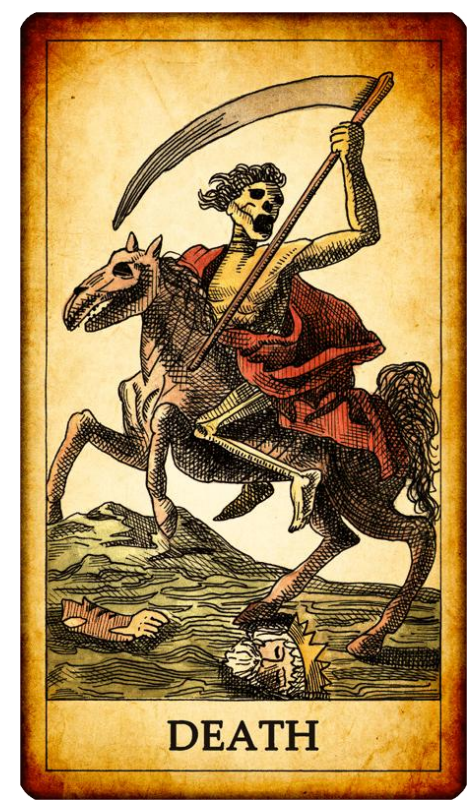

Such an image is surely limited. It does not picture death in all its aspects. We can say that its metaphorical representative power is less than the one of a dodecagon to represent a chiliagon. From a dodecagon we can imagine what a chiliagon is, the euphemism being purely quantitative and quite straightforward. And the difference is that not only it is difficult to imagine death, but also difficult to conceive it. A biological view of death is only partial and does not really explain what death is. Can we conceive what we will be when we will die? 




\section{Acknowledgments}

This study about the relations between possibility, imagination and conception (PIC) started with some discussions I had with Alexandre CostaLeite and Gillman Payette in 2007, the former being interested to develop a logic of imagination. In December 2007 I organized an interdisciplinary congress on imagination at the University of Neuchâtel, Switzerland; together with Catherine Chantilly (a DVD of this event is available on request). I also gave in 2007 a course on imagination at the Institute of Psychology of this University, institute directed at this time by Anne-Nelly Perret Clermont. Since then I gave talks on this PIC topic along the years in many universities around the world (Geneva, Beijing, Lisbon, Natal, São Paulo, Frankfurt, Montreal, Bern, Paris etc.) and I also organized a workshop on this topic at the 23th World Congress of Philosophy in Athens, Greece in 2013. ${ }^{15}$ I finally started to write this paper during my visit at the University of California, San Diego supported by a CAPES grant (BEX 2408/14-07) and invited by Gila Sher.

\footnotetext{
${ }^{15}$ At this occasion I presented, as the director of international relations of the Brazilian Academy of Philosophy (ABF), the candidacy of Rio de Janeiro for the next edition of the WCP (World Congress of Philosophy) projected to happen in 2018, with Imagination as the main topic. Brazil lost against China, so the 24th WCP will happen in Beijing in 2018 with Learning to be human as the main topic. It is conceivable and possible to have the next next WCP in Rio de Janeiro in 2023 on Imagination; we have received support in this sense.
} 
90

Thanks to Saloua Chatti, Renato Mendes Rocha, Yvon Gauthier and anonymous referees who helped by their comments to improve the paper.
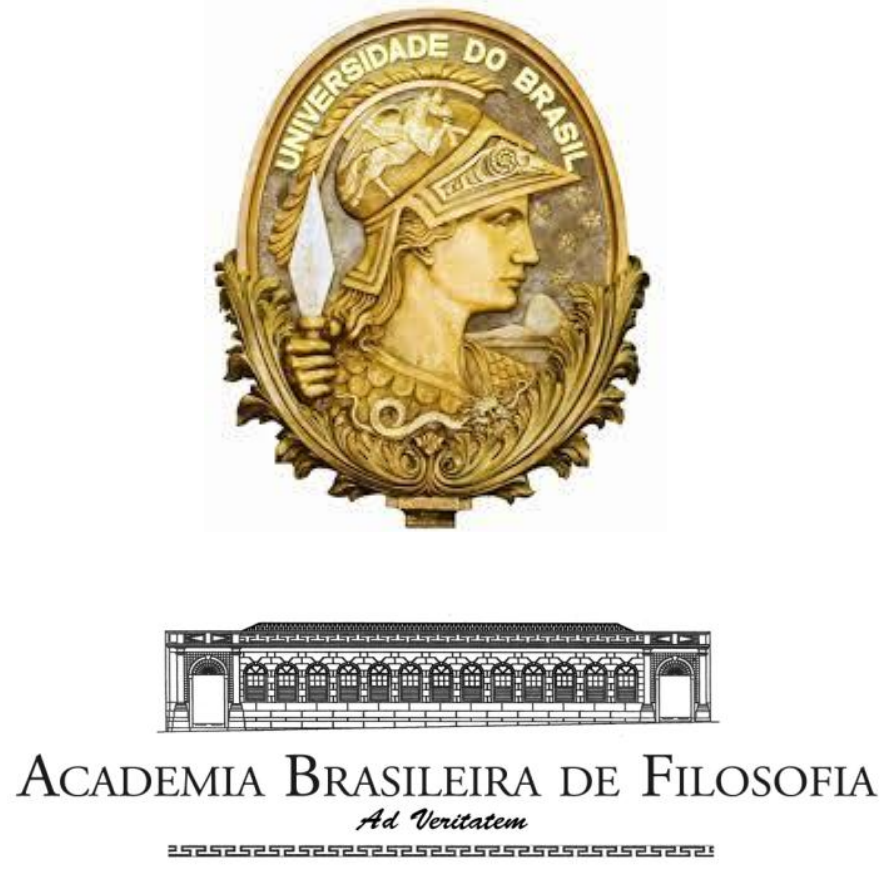

Glória, Rio de Janeiro, March 27, 2016.

\section{Bibliography}

BAZHANOV, V. Nicolai Vasiliev. In: FIESER, J.; DOWDEN, B. (Ed.)

Internet Encyclopedia of Philosophy, 2016. (forthcoming.)

BECKER ARENHART, J. R. Liberating Paraconsistency from

Contradiction. Logica Universalis, v. 9, issue 4, 2015, p. 523-544. 
BEZIAU, J.-Y. L'holomouvement chez David Bohm. (Master thesis, directed by Barnard d'Espagnat, University Paris 1 - Panthéon Sorbonne). Paris, 1987.

BEZIAU, J.-Y. D'une caverne à l'autre. (DEA thesis, directed by Sarah Kofman, University Paris 1 - Panthéon Sorbonne). Paris, 1988.

BEZIAU, J.-Y. The new rising of the square of opposition. In: BEZIAU, J.Y.; JACQUETTE, D. (Ed.). Around and beyond the square of opposition. Birkhäuser: Basel, 2012. p. 6-24.

BEZIAU, J.-Y. The power of the hexagon. Logica Universalis, v. 6, issue 1, 2012, p. 1-43.

BEZIAU, J.-Y. La puissance du symbole. In: BEZIAU, J.-Y. (Ed.). La pointure du symbole. Paris: Petra, 2014. p. 9-34.

BEZIAU, J.-Y. Round squares are no contradictions (tutorial on negation, contradiction and ppposition). In: BEZIAU, J.-Y.; CHAKRABORTY, M.; DUTTA, S. (Ed.). New directions in paraconsistent logic. New Delhi: Springer, 2015. p. 39-55.

BEZIAU, J.-Y. Le possible et l'impossible: au-delà de la dichotomie. In: CONGRÈS DE L'ASPLF, 35 (Rabat, Maroc, 26-30 Août, 2014). Actes. Paris: Vrin, 2016. p. 53-74

BEZIAU, J.-Y. The contingency of possibility. Principia, v. 20, 2016. (forthcoming.)

BEZIAU, J.-Y. Is modern logic non-Aristotelian? In: ZAITSEV, D. (Ed.), Nikolai Vasiliev's logical legacy and modern logic. Dordrecht: Springer, 2016.

BEZIAU, J.-Y. Disentangling contradiction form contrariety via incompatibility. Logica Universalis, v. 10, issue 2-3, 2016, p. 157-170.

BEZIAU, J.-Y. Prototypical conceptual analysis. (forthcoming.) 
BEZIAU, J.-Y.; PAYETTE, G. (Ed.). Special issue of Logica Universalis on the square of opposition, v. 2, issue 1, 2008.

BEZIAU, J.-Y.; PAYETTE, G. (Ed.). The square of opposition: a general framework for cognition. Bern: Peter Lang, 2012.

BEZIAU, J.-Y.; JACQUETTE, D. (Ed.). Around and beyond the square of opposition. Birkhäuser: Basel, 2012.

BEZIAU, J.-Y.; READ, S. (Ed.). Special issue of History and Philosophy of Logic on the history of the square of opposition, v. 35, issue 4, 2014.

BEZIAU, J.-Y.; KRAUSE, D.; BECKER ARENHART, J. R. (Ed.). Conceptual clarifications: tributes to Patrick Suppes (1922-2014). London: College Publications, 2015.

BEZIAU, J.-Y.; GAN-KRZYWOSZYNSKA, K. (Ed.). New dimensions of the square of opposition. Berlin: Philosophia, 2016.

BEZIAU, J.-Y.; BASTI, G. (Ed.). The square of opposition: a cornerstone of thought. Basel: Birkhäuser, 2016.

BEZIAU, J.-Y.; GIOVAGNOLI, R. (Ed.). Special issue of Logica Universalis on the square of opposition, v. 10, issue 2-3, 2016.

BLANCHÉ, R. Structures intellectuelles: essai sur l'organisation systématique des concepts. Paris: Vrin, 1966.

BOHM, D. Wholeness and the implicate order. London: Routledge, 1983.

BYRNE, A. Possibility and imagination. Philosophical perspectives. 21, 2007, p. 125-144.

BUNGE, M. Foundations of physics. New York: Springer, 1967. 
CHALMERS, D. Does conceivability entails possibility? In: GENDLER, T. S.; HAWTHORNE, J. (Ed.). Conceivability and possibility. Oxford: Oxford University Press, 2002. p. 145-200.

CHOUDHURY, L.; CHAKRABORTY, M. H. Singular propositions, negation and the square of opposition. Logica Universalis, v. 10, issue 2-3, 2016, p. 215-231.

da COSTA, N. C. A. Sistemas formais inconsistentes. Curitiba: Universidade Federal do Paraná, 1963.

COSTA-LEITE, A. Logical properties of imagination. Abstracta, v. 6, n. 1, 2010, p. 103-116.

D'ESPAGNAT, B. Le réel voile: analyse des concepts quantiques. Paris: Fayard, 1994.

GENDLER, T. S.; HAWTHORNE, J. (Ed.). Conceivability and possibility. Oxford: Oxford University Press, 2002.

HUMBERSTONE, L. Modality. In: JACKSON, F. C.; SMITH, M. (Ed.). Oxford handbook of Contemporary Philosophy. Oxford: Oxford University Press, 2005. p. 534-614.

JASPERS, D. Logic and colour. Logica Universalis, v. 6, issue 1-2, 2012, p. 227-248.

KIND, A. Imagery and imagination. In: FIESER, J.; DOWDEN, B. (Ed.) Internet Encyclopedia of Philosophy, 2016.

$<$ http://www.iep.utm.edu/imagery $>$.

JAŚKOWSKI, S. A propositional calculus for inconsistent deductive systems. Logic and Logical Philosophy, 7, 1999, p. 35-56. (Original in Polish 1948.) 
94

\section{Possibility, imagination and conception}

LACHANCE, G. Platonic contrariety (enantia): ancestor of the Aristotelian notion of contradiction (antiphasis)?. Logica Universalis, v. 10, issue 2-3, 2016, p. 143-156.

LÉVY-LEBLOND, J.-M.; BALIBAR, F. Quantique (Rudiments). Paris: Masson, 1997.

LIPSON, A. Escher's “waterfall” in Lego. 2003.

$<$ http://www.andrewlipson.com/escher/waterfall.html >.

MAGNANI, L. Violence hexagon - Moral Philosophy through drawing. Logica Universalis, v. 10, issue 2-3, 2016, p. 359-371.

NELSEN, R. B. Proofs without words: exercises in visual thinking. Washington: Mathematical Association of America, 1997 (Vol. I); 2000 (Vol. II).

NICHOLS, S. (Ed.). The architecture of imagination, Oxford: Oxford University Press, 2006.

MAXIMOV, D. Y. "N. A. Vasil'ev's logical ideas and the categorical semantics of many-valued logic". Logica Universalis, v. 10, issue 1, 2016, p. 21-43.

PARROCHIA, D.; NEUVILLE, P. Towards a general theory of classification, Basel: Birkhäuser, 2013.

SHIN, S.-J.; MOKTEFI, A. Visual reasoning with diagrams. Basel: Birkhäuser, 2013.

SUPPES, P.; BEZIAU, J.-Y. Semantic computation of truth based on associations already learned. Journal of Applied Logic, 2, 2004, p. 457467.

TARSKI, A. The semantic conception of truth and the foundations of semantics. Philosophy and Phenomenological Research, 4, 1944, p. 341376. 
VAIDYA, A. The epistemology of modality. In: ZALTA, E. N. (Ed.). Stanford Encyclopedia of Philosophy. Stanford: Metaphysics Research Lab, 2007; rev. ed. 2015. < http://plato.stanford.edu/entries/modalityepistemology $>$.

YABLO, S. Is conceivability a guide to possibility? Philosophy and Phenomenological Research, 53, 1993, p. 1-42.

Artigo recebido em 13/12/2015, aprovado em 8/02/2016 